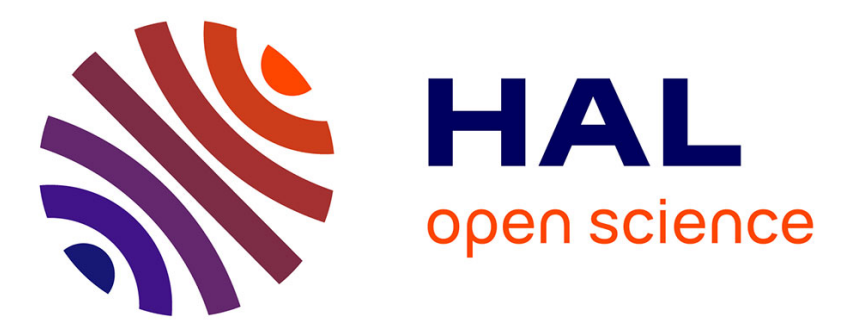

\title{
Experimental investigation on mean crushing stress characterization of carbon-epoxy plies under compressive crushing mode
}

\author{
Haris Ahmad Israr, Samuel Rivallant, Jean-Jacques Barrau
}

\section{To cite this version:}

Haris Ahmad Israr, Samuel Rivallant, Jean-Jacques Barrau. Experimental investigation on mean crushing stress characterization of carbon-epoxy plies under compressive crushing mode. Composite Structures, 2013, vol. 96, pp.357-364. 10.1016/j.compstruct.2012.09.022 . hal-00784973

\section{HAL Id: hal-00784973 \\ https://hal.science/hal-00784973}

Submitted on 5 Feb 2013

HAL is a multi-disciplinary open access archive for the deposit and dissemination of scientific research documents, whether they are published or not. The documents may come from teaching and research institutions in France or abroad, or from public or private research centers.
L'archive ouverte pluridisciplinaire HAL, est destinée au dépôt et à la diffusion de documents scientifiques de niveau recherche, publiés ou non, émanant des établissements d'enseignement et de recherche français ou étrangers, des laboratoires publics ou privés. 


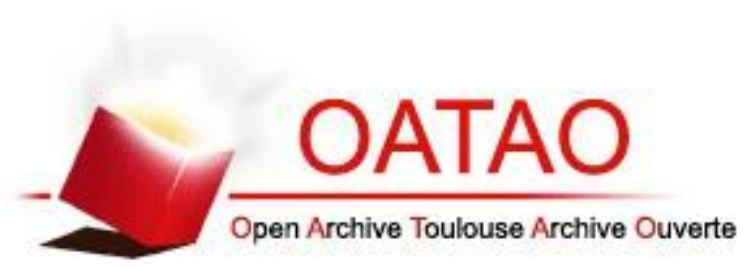

\section{Open Archive Toulouse Archive Ouverte (OATAO)}

OATAO is an open access repository that collects the work of Toulouse researchers and makes it freely available over the web where possible.

This is an author-deposited version published in: http://oatao.univ-toulouse.fr/ Eprints ID: 7934

To link to this article: DOI: $10.1016 / \mathrm{j}$. compstruct.2012.09.022

URL: http://dx.doi.org/10.1016/j.compstruct.2012.09.022

To cite this version: Israr, Haris Ahmad and Rivallant, Samuel and Barrau, Jean-Jacques Experimental investigation on mean crushing stress characterization of carbon-epoxy plies under compressive crushing mode. (In Press: 2013) Composite Structures, vol. 96. pp. 357-364. ISSN 02638223

Any correspondence concerning this service should be sent to the repository administrator: staff-oatao@inp-toulouse.fr 


\title{
Experimental investigation on mean crushing stress characterization of carbon-epoxy plies under compressive crushing mode
}

\author{
H.A. Israr ${ }^{\mathrm{a}, \mathrm{b}}$, S. Rivallant ${ }^{\mathrm{a}, *}$, J.J. Barrau ${ }^{\mathrm{a}}$ \\ a Université de Toulouse; ISAE, INSA, UPS, Emac; ICA (Institut Clement Ader). ISAE (Institut Supérieur de l'Aéronautique et de l'Espace), 10 Avenue Edouard Belin, BP 54032, \\ 31055 Toulouse Cedex 4, France \\ ${ }^{\mathrm{b}}$ Faculty of Mechanical Engineering, Universiti Teknologi Malaysia, 81310 UTM Skudai, Johor, Malaysia
}

\section{A R T I C L E I N F O}

Keywords:

Crashworthiness

Mean crushing stress

CFRP

Laminates

Compressive

\begin{abstract}
A B S T R A C T
A challenge in numerical simulation of crashworthiness study is to be able to predict the crush damage modes, their evolution during crushing and the energy absorption in any composite structure from elementary material characterisation data. Therefore, it is important to know the behavior of one ply subjected to crushing load, and especially to determine the mean crushing stress that could be used for simulation. For that purpose, quasi-static crushing tests are performed for different configurations of two CFRP materials, UD and fabrics to determine the mean crushing stress of plies alone and inside a laminate. This study shows there is a linear relationship between crushing load and the contact surface of the plies being crushed on a metallic base which enables actually to define a mean crushing stress for a ply. The method to calculate this value is presented in this paper, based on image analysis of specific crushing tests. Experimental results show that for the UD material, the mean crushing stresses in $0^{\circ}$ and $90^{\circ}$ plies are very close. The value for a balanced fabric is also similar, approximately $270 \mathrm{MPa}$.
\end{abstract}

\section{Introduction}

Composite materials are progressively replacing metals in the vehicle structures design because of their technical advantages especially their high strength to weight ratio. Nevertheless, the specificity and complexity of composite fractures modes make difficult the prediction of their behavior subjected to crush loads due to a great number of parameters such as geometry, laminate sequences, mechanical properties, contact and friction [1-3]. The development of composite crashworthiness test programs to validate design variants through experimental works increase drastically the design costs. The increase in performance of computers and numerical modeling software gives opportunity to the industry to consider the use of such tools to address the design issue and the crashworthiness problem by developing numerical modeling in order to minimize experimental tests costs.

Simulating the crushing process of a composite structure must be capable to describe the initiation and progression of a crushing mode right up to the point of final failure. In contrast to ductile metals, which mainly absorb energy by plasticity during crash, composite structures absorb energy through combination of

* Corresponding author. Address: ISAE/DMSM, 10 Avenue Edouard Belin, BP 54032, 31055 Toulouse Cedex 4, France. Tel.: +33 561338158; fax: +33 561338352.

E-mail addresses: haris583@yahoo.com (H.A. Israr), samuel.rivallant@isae.fr (S. Rivallant), barrau@cict.fr (J.J. Barrau). fracture mechanisms, which involve fiber fracture, intra- and inter-laminar matrix cracking, fiber-matrix debonding and delamination [1], all of which at a micro or mesoscopic (sub-ply) scale. This means that in order to be able to represent these mechanisms in a crushing numerical simulation, it requires a detailed finite element model at the scale of these observed phenomena.

From an experimental and numerical point of view, the crushing is often used to understand, analyze or calculate a structure subjected to crushing. Even if the crushing stress is defined as the mean crushing load divided by the cross sectional area, which is not a material characteristic, but a structure dependent value.

For example, Mamalis et al. [2] has reported that mechanism controlling the crushing process is dependent on the rate of applied stress, therefore it could be said that the crush stress is an important criteria. Barnes et al. [3] reported that the crushing stress in composite structures is dependent on material and geometric parameters, i.e. fiber and resin type, fiber orientations, and volume fractions of the constituent materials, but they also added that when designing an energy absorbing structure using composites the mean crushing stress is a critical design parameter that must be known. Besides that, the mean crushing stress was found considerably lower than the compressive strength.

For the last two decades many studies have investigated on the effect of the type of composite material [4,5], laminate design [1,6], specimen geometry [7-9], processing condition [10], fracture toughness $[11,12]$ or crushing mechanisms $[13,14]$ on the energy 
absorption capabilities of structural components. But just a few discussions $[10,15,16]$ concerning the mean crushing stress or specific sustained crushing stress (SSCS) have been done in the past.

Melo et al. [10] have investigated the effect of the application of vacuum on composite structures during fabrication on the energy absorption capability. According to their results, it did not produce any significant effect on mean crushing stress or either compressive strength. In fact, the SEA is proved to be dependent on the cross section geometry. Furthermore, Savona and Hogg [15] studied the relation between SSCS of glass fiber reinforced plastic (GFRP) composite plates in function of their Mode-I and Mode-II fracture toughness properties. They found that the magnitude of the mean force depends on the propagation of the inter- and intra-laminar cracks. In addition, materials which have low Mode-I and Mode-II inter-laminar fracture toughness caused low SSCS and as a result, the energy absorbed during crushing is also low. They also added that the energy absorption of composite plates is mainly controlled by the shear cracking phenomena that strongly depend on the properties of Mode-II fracture toughness. Farley and Jones [16] used SSCS as an indicator to see the effect of ply angle $[ \pm \theta]$ on the energy absorption capability of composite tube. Based on their results, the SSCS for ply oriented nearly $0^{\circ}$ and $90^{\circ}$ is close to each other for material Kevlar-934. However, these studies focused on drawing the relationship between specific energy absorption (SEA) and material properties which involve global mean crushing stress.

Greve et al. [17] on the other hand has introduced new simulation technique of phenomenological modeling based on Energy Absorbing Contact (EAC) formulation that depends on the global fragmentation stresses obtained from a series of dynamic axial and oblique impact tests. However, this fragmentation stress depends on the laminate lay-up, geometry (thickness) and impact angle. Thus, it needs to be determined each time the specimen and test configurations change which increases cost and time consuming.

A limitation of most of these studies is that the crushing stress (or SEA) being a global structure and material dependent parameter, it can be used as a performance indicator, but not to predict the complex behavior of a composite structure subjected to crushing. It would then be interesting to investigate if it is possible to define a mean crushing stress for an elementary ply, which would then be an intrinsic parameter of the material. To the author's knowledge, there is no study concerning the mean crushing stress of a ply in the literature.

The results of experimental quasi-static crushing tests done by Duong et al. [18] has shown that during a test, the number of plies being crushed in a local fragmentation mode can vary, and it seems that this number is linear with the applied load. Hence, it seems to show the possibility to determine a local mean crushing stress for the plies used in these tests.

Currently, there are no standards or appropriate test methods to determine the local mean crushing stress of a ply. Therefore, in this paper an experimental methodology is introduced to determine the local mean crushing stress of carbon-epoxy plies. Crushing tests are performed on pure $0^{\circ}$, pure $90^{\circ}$, and mixed $0^{\circ}$ and $90^{\circ}$ UD laminates, and also on fabrics. Pictures of the crushing front are recorded and analyzed to determine the size of the surface in contact during crushing. From this surface, and from the load, a stress can be calculated for $0^{\circ}$ and $90^{\circ}$ plies. We verified that this stress is not dependent of the test configuration, which allows defining it as the mean crushing stress of a ply. The values obtained are compared together, and to the usual compressive strength of a ply.

\section{Experimental setup}

\subsection{Materials}

Two different materials were used in this study. The first material is Hexcel carbon epoxy unidirectional (UD) prepreg T700/M21. The matrix Hexflow M21 consists of a mix of a duroplastic epoxy resin and thermoplastic constituents. Besides that, the matrix weight proportion is $35.5 \%$. The thickness of each ply is $0.26 \mathrm{~mm}$. The second material is Cytec balanced fabric 5H (6KHTA) 977-2 carbon epoxy. The mechanical properties of fabric 5H (6KHTA) 977-2 are obtained from the constructor. The ply thickness for this material is $0.35 \mathrm{~mm}$.

\subsection{Specimen}

Specimens are cut out of laminated plates. There are two plates made from material T700/M21. The first one is a UD laminate made of 8 plies that are used to determine the mean crushing stress of plies alone in pure longitudinal direction $\left[\left(0^{\circ}\right)_{8}\right]$ (specimen T-0) and pure transverse direction $\left[\left(90^{\circ}\right)_{8}\right]$ (specimen T-90). The second plate (T-0/90) is used to study the mean crushing stress of plies inside a laminate specimen with laminate design consist of 16 plies with stacking sequence of $\left[\left(0^{\circ} / 90^{\circ}\right)_{4}\right] \mathrm{sym}$. Meanwhile for the Cytec balanced fabrics 5H (6KHTA) 977-2 only one plate (C-0) is used in this study with stacking sequence $\left[\left(0^{\circ}\right)_{12}\right]$.

The plates from both materials were cut to produce small specimens with short length and small width varying from $8 \mathrm{~mm}$ to $10.5 \mathrm{~mm}$. This small length (from 55 to $65 \mathrm{~m}$ ) is considered enough in order to have both the initiation step and a steady crushing front

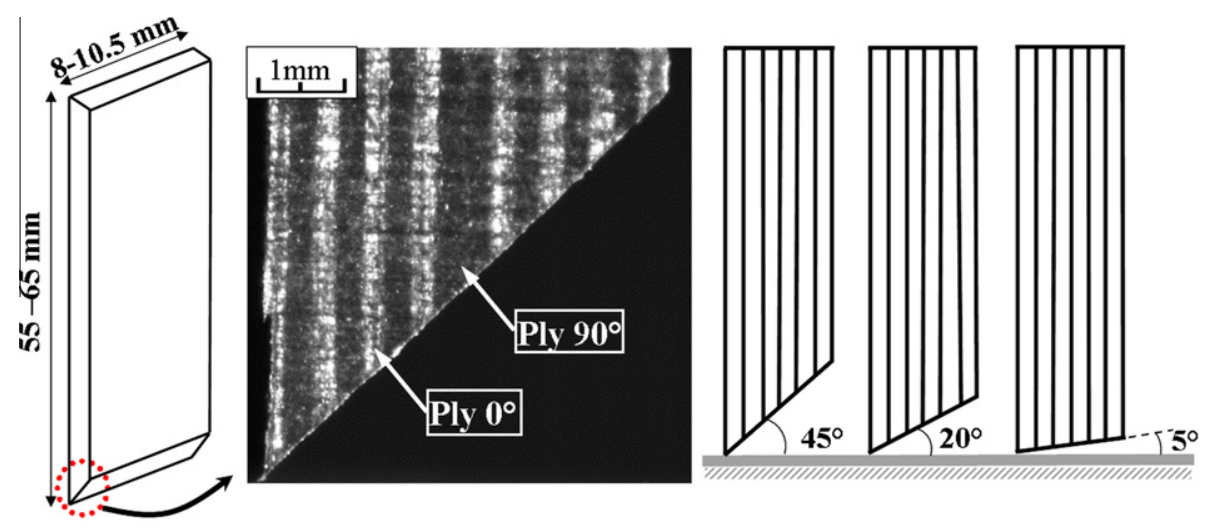

(a)

(b)

(c)

Fig. 1. Specimen description: (a) geometry, (b) T-0/90 chamfering detail, and (c) chamfer angles. 
Table 1

Specimen geometry configurations.

\begin{tabular}{lll}
\hline Specimen $^{\mathrm{a}}$ & Thickness $(\mathrm{mm})$ & Width $(\mathrm{mm})$ \\
\hline $\mathrm{T}-0-20^{\circ}-\mathrm{n} 1$ & 2.11 & 10.23 \\
$\mathrm{~T}-0-45^{\circ}-\mathrm{n} 1$ & 2.11 & 10.22 \\
$\mathrm{~T}-90-20^{\circ}-\mathrm{n} 1$ & 2.11 & 10.16 \\
$\mathrm{~T}-90-45^{\circ}-\mathrm{n} 1$ & 2.11 & 10.13 \\
$\mathrm{~T}-90-45^{\circ}-\mathrm{n} 2$ & 2.11 & 10.13 \\
$\mathrm{~T}-0 / 90-20^{\circ}-\mathrm{n} 1$ & 4.26 & 8.32 \\
$\mathrm{~T}-0 / 90-45^{\circ} \mathrm{n} 1$ & 4.26 & 8.34 \\
$\mathrm{~T}-0 / 90-45^{\circ}-\mathrm{n} 2$ & 4.26 & 8.30 \\
$\mathrm{C}-0-5^{\circ}-\mathrm{n} 1$ & 4.71 & 8.09 \\
$\mathrm{C}-0-20^{\circ}-\mathrm{n} 1$ & 4.71 & 8.04 \\
$\mathrm{C}-0-45^{\circ}-\mathrm{n} 1$ & 4.71 & 8.14 \\
\hline
\end{tabular}

a Note: The designation of specimens was based on the code [M-S- $\left.\mathrm{C}^{\circ}-\mathrm{n}\right]$ where; $\mathrm{M}$ : material, S: stacking sequence, $\mathrm{C}^{\circ}$ : chamfering angle, $\mathrm{n}$ : number of the specimen.

which gives different configurations of specimen fragmentation in the same test. Besides that, one extremity of the specimens was cut to form a chamfering-type trigger mechanism. Three different chamfering angles were used in this study as shown in Fig. 1 in order to have different crush morphologies at crush front and afterwards be able to determine the overall average of mean crushing stress of all cases.

In general, 11 specimens were used in this study. There is only few in number of specimens, but one must see that each test provides a wide range of force/surface contact configurations (as much as the number of images taken during tests). Before the compressive tests, all specimens were measured for the calculation of the cross-sectional area. The summary of all specimen geometry configurations is listed in Table 1.

\subsection{Test setup}

Quasi-static crushing tests were carried out for all specimens at a constant loading speed, and therefore, are easy to control and may able to observe precisely the crushing mechanisms as reported by many authors that also used quasi-static tests in their study concerning crashworthiness capability of composite structures $[19,20]$. In this study the quasi-static crushing tests were performed using Hydraulic Instron testing machine in compression testing mode. The specimens were clamped in the moving grip and the metallic base on which specimen are crushed is fixed. All tests were conducted under a displacement-controlled mode at a constant loading rate of $6 \mathrm{~mm} / \mathrm{min}$. Fig. 2 shows the test set-up and the location of specimen.

The force-displacement data have been recorded, acquired at rate $100 \mathrm{~Hz}$. To avoid global buckling and too much bending, the non-clamping length is limited to $30 \mathrm{~mm}$ for the laminate specimens and $10 \mathrm{~mm}$ for the thinner UD specimens. For the laminate specimens, tests were interrupted after $10 \mathrm{~mm}$ crushing displacement while $6 \mathrm{~mm}$ displacement for the UD specimens, which was considered enough to allow the determination of the mean crushing stress.

Two cameras were used to capture the images of crushing process every $0.1 \mathrm{~mm}$ of displacement during the experiment. These two cameras were placed at both sides (front and back respectively) to have complementary information for contact area calculation. Besides that, only a small area is captured by the camera approximately $10 \mathrm{~mm} \times 10 \mathrm{~mm}$ because only this area is important to observe for measurement of the contact length between plies that have local crushing and the metallic base. Image resolutions approximately $100 \mathrm{pixel} / \mathrm{mm}$. Acquisition is performed at $1 \mathrm{~Hz}$

\section{Calculation method}

\subsection{Contact length measurement}

The aim is to calculate the local mean crushing stress, thus, it is necessary to define the right contact area of local crushing. The contact area is computed by multiplying the contact length with the width of specimen. The definition of contact length in this study is the direct contact between the plies and the metallic base that enable to sustain the forces.

Since the specimens have been chamfered at one end of the plate, most of the specimens are experiencing mixed mode crushing morphology except the T-90 specimens. From the observation of Fig. 3, the number of plies having direct contact with metallic base seems to be proportional to the force measured during the test. Thus, it would demonstrate the linear relationship between the direct contact area and the measured force.

From the beginning to image 1, the tip of the specimen crushes with local fragmentation (mostly) and the force grows as the contact area increases. Then, the delamination appears with splaying plies due to high transverse shear stress in plies interfaces, leading to a severe drop in the force (images 2 to 3 ). Between images 3 and 4 , a mixed mode phenomenology appears with fragmentation in the middle plies, increasing the force. As well as the number of plies in fragmentation decreases from images 4 to 6 , the force correspondingly declines.

Therefore, for the contact area measurement only contact length of plies in fragmentation is counted as they enable to sustain forces as shown in Fig. 4. In addition, there are some plies having "small bending" (short length ply bending), with still fragmentation at tip that also enable to sustain the force. Thus, the contact areas of these plies are included in the calculation (Fig. 4a).

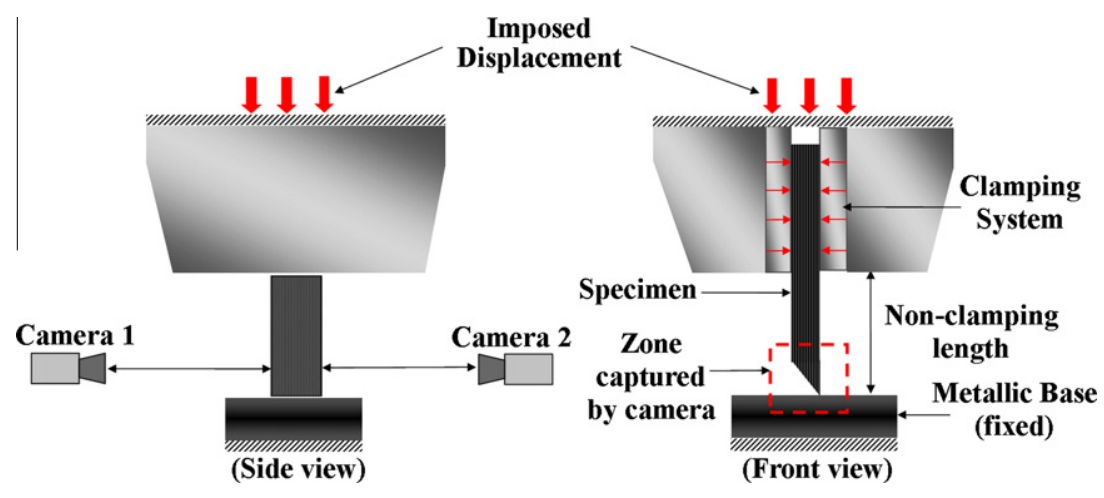

Fig. 2. Test set-up. 

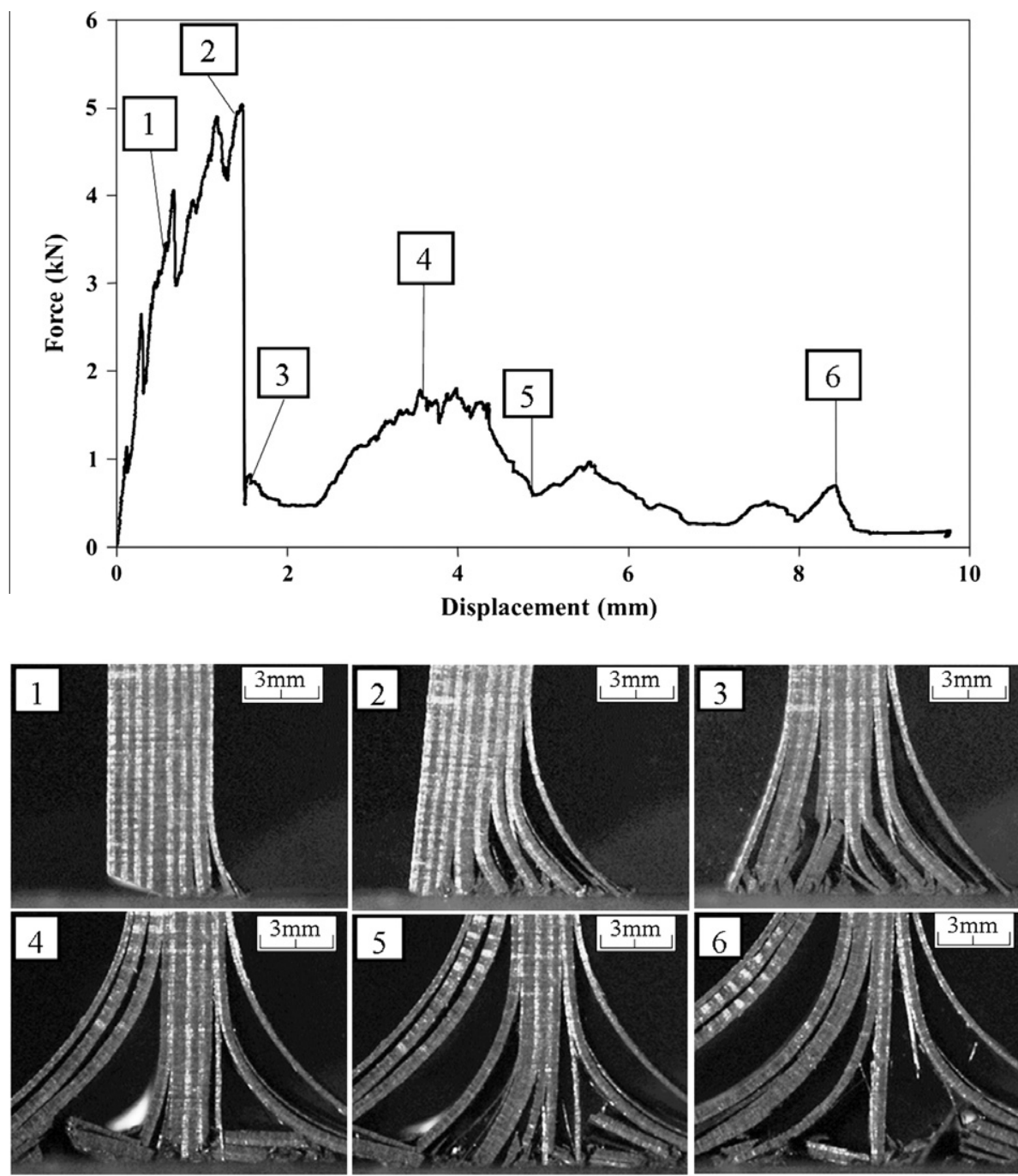

Fig. 3. Example of force-displacement curve of $\mathrm{T}-0 / 90-20^{\circ}$ test and selected pictures of the crushing front.

However, during crushing the plies in fragmentation also sustain severe damage that generates debris accumulation which reduces the contact area of plies in fragmentation. Thus, it must be careful not to include together the length of debris because it makes the correlation between contact surface and force become unrealistic as debris has no direct contact, then no sustainable force (Fig. 4a and d).

On the other hand, the contact area of plies in the splaying mode (Fig. $4 \mathrm{a}-\mathrm{c}$ ) is considered negligible. These plies generate very low bending force. Guillon [21] has made comparison tests between pure splaying mode and pure fragmentation mode of crushing tests, and proved that the load in pure splaying mode is only $1 \%$ compared to the mean crush load in pure fragmentation mode.

As the mean crushing stress is assumed not to be the same in $0^{\circ}$ and $90^{\circ}$ plies, for laminate specimens, contact areas of plies at $0^{\circ}$ and $90^{\circ}$ were measured separately in order to be able to determine the local mean crushing stress for each ply orientation.

Of course, determining the contact length from the images is not an easy task. During calculation of the contact length on certain images, it is recommended to view the image before and image after current images in order to make sure not to miss any important information especially regarding the contact length at the extremity for instance to avoid including the debris into the calculation. Furthermore, the measurement is done on both side images (two cameras) to ensure it gives same results, and help for determining the contact area.

There are some obstacles in measuring the contact length due to the quality of images, for example debris that hindering the vision, plies in contact with metallic base that are already broken at above which do not generate any forces, too much flare in the images, etc. Thus, the measurement is not possible to do for each image and the ambiguous images were removed from the calculation process.

Finally, determination of contact area was made entirely independently from the recorded data (force), not to have any bias in the method (only a few points of calculation were removed after calculation of mean crushing stress, for which new observations revealed mistake in the calculation of contact length). The contact length for each specimen is calculated and plotted in function of time together with the experiment measured force as example in Fig. 5. It shows similarities in the curve shapes. In the case of UD, $0^{\circ}$ or $90^{\circ}$, there is clearly proportionality (see example for $0^{\circ}$, Fig. 5a), but in the case of laminate (T-0/90), it is more complex to see due to the two considered parameters; contact length of $0^{\circ}$ and $90^{\circ}$ plies (Fig 5b). The ratio between contact length of $0^{\circ}$ and $90^{\circ}$ plies is drawn in Fig. $5 \mathrm{~b}$ below the crushing force and shows that during a test, the percentage of $0^{\circ}$ plies in the calculation of crushing length can vary from $30 \%$ to $90 \%$. 

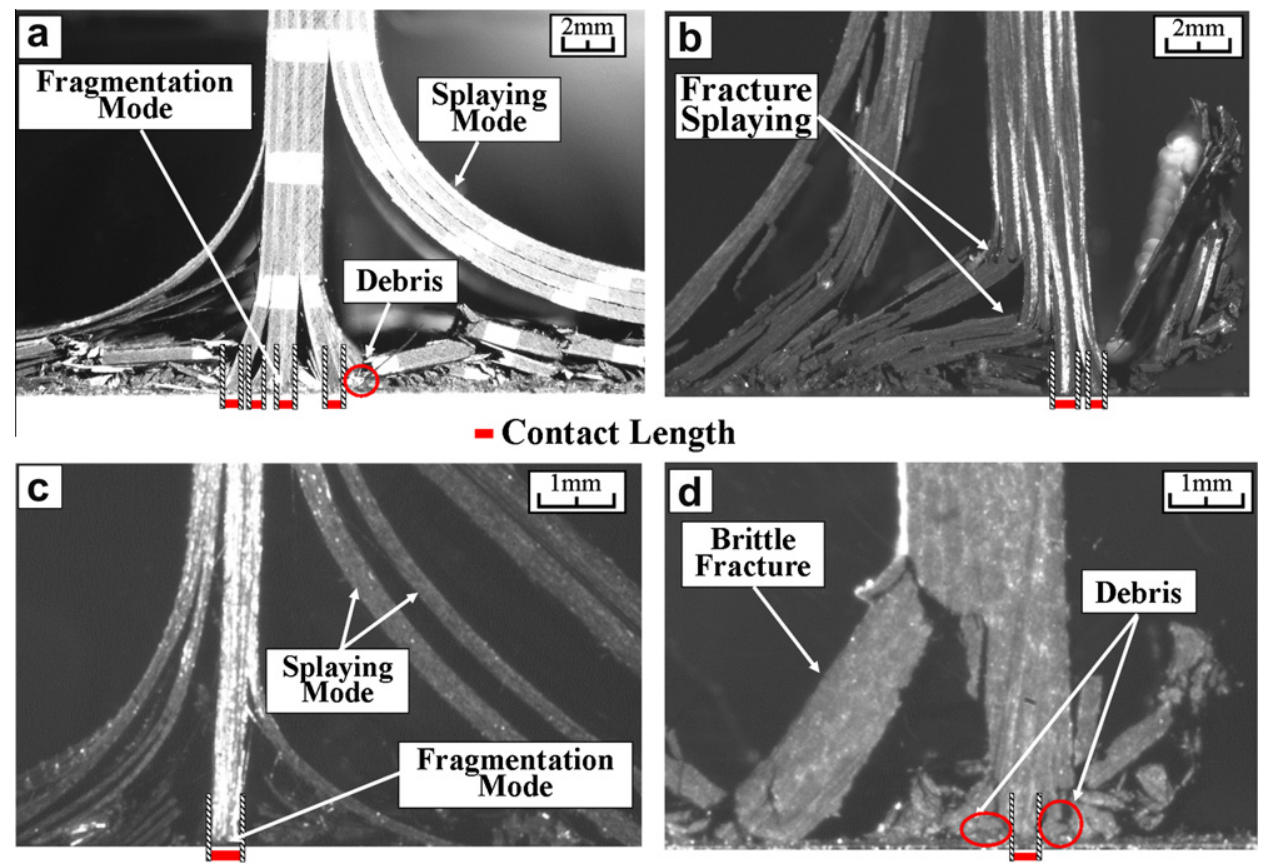

Fig. 4. Contact length definition: (a) T-0/90, (b) C-0, (c) T-0, and (d) T-90.

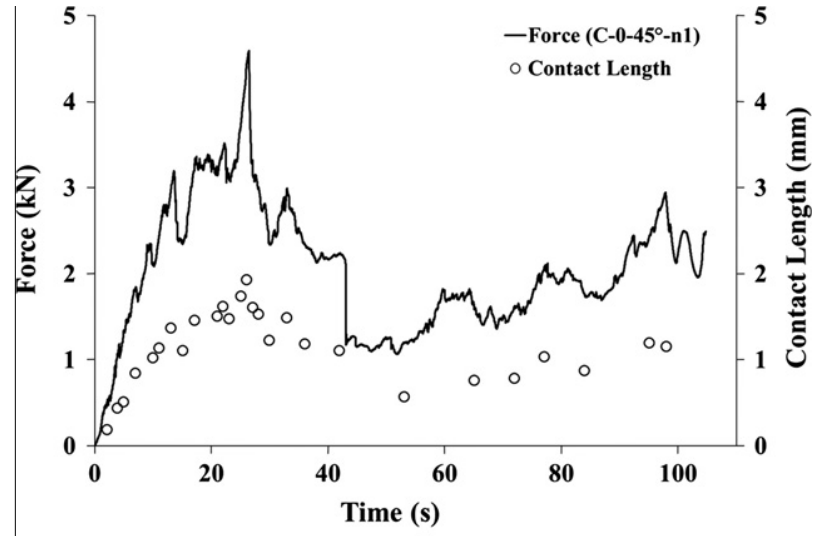

(a)

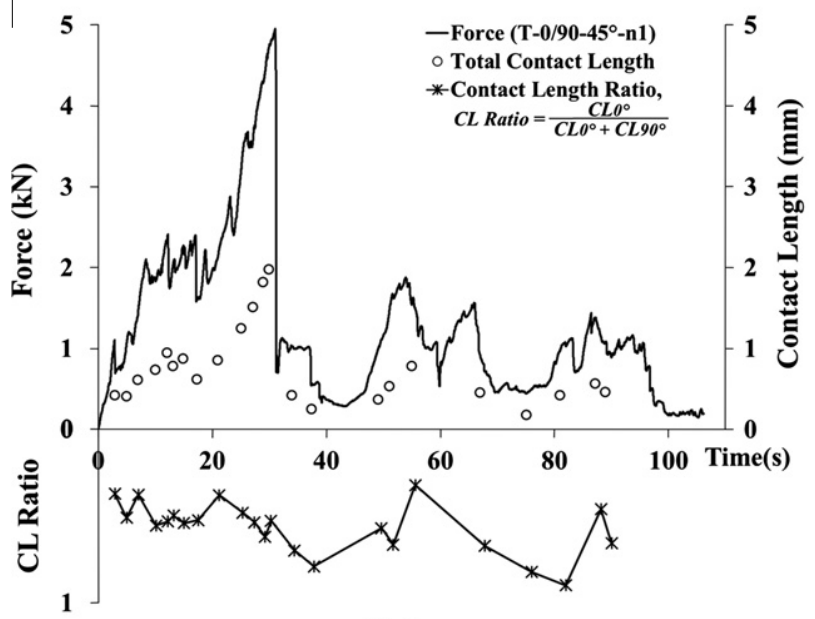

(b)

Fig. 5. Examples of contact length and force curve: (a) laminate $C-0$, and (b) laminate $\mathrm{T}-0 / 90$.

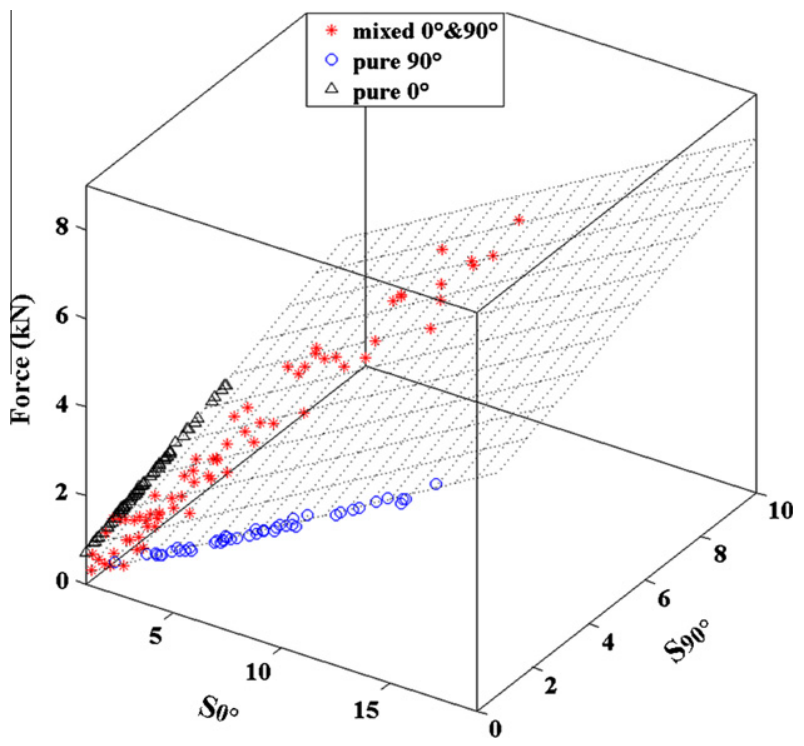

Fig. 6. Range of contact area and global correlation for T700/M21 specimens.

\subsection{Least mean square analysis}

From the similarity of curve shapes between force and contact length observed in Fig. 5, model A (Eq. (1)) is proposed to estimate the mean crushing stress of ply for the case of UD (T-0 and T-90) and balanced fabrics (C-0) specimens.

$F=\sigma_{0^{\circ}} S_{0^{\circ}}+F_{\text {splaying }}\left(\right.$ or $\left.F=\sigma_{90^{\circ}} S_{90^{\circ}}+F_{\text {splaying }}\right)$

where $F$ is the force, $\sigma_{0^{\circ}}\left(\sigma_{90^{\circ}}\right)$ is the mean crushing stress for $0^{\circ}$ $\left(90^{\circ}\right)$ plies, $S_{0^{\circ}}\left(S_{90^{\circ}}\right)$ is the contact area of $0^{\circ}\left(90^{\circ}\right)$ crushing plies and $F_{\text {splaying }}$ is the splaying force.

Afterwards, the prediction model B (Eq. (2)) is introduced as an extension from model $\mathrm{A}$ for $\mathrm{T}-0 / 90$ specimens since it has two parameters, crushing area of $0^{\circ}$ and $90^{\circ}$ ply. Therefore, the local 
Table 2

Estimation of mean crushing stress of plies inside laminates.

\begin{tabular}{|c|c|c|c|c|c|}
\hline $\begin{array}{l}\text { T700/M21 } \\
\text { Specimen }\end{array}$ & \multicolumn{2}{|c|}{$\begin{array}{l}\text { No. of points for } \\
\text { LMS calculation }\end{array}$} & \multirow{2}{*}{$\begin{array}{l}\begin{array}{l}\sigma_{0^{\circ}} \\
(\mathrm{MPa})\end{array} \\
274\end{array}$} & \multirow{2}{*}{$\begin{array}{l}\sigma_{90^{\circ}} \\
(\mathrm{MPa})\end{array}$} & \multirow{2}{*}{$\begin{array}{l}\begin{array}{l}\text { Standard } \\
\text { deviation (\%) }\end{array} \\
4\end{array}$} \\
\hline $\mathrm{T}-0-20^{\circ}-\mathrm{n} 1$ & 25 & & & & \\
\hline $\mathrm{T}-0-45^{\circ}-\mathrm{n} 1$ & 24 & & 271 & - & 3 \\
\hline T- $90-20^{\circ}-n 1$ & 37 & & - & 259 & 2 \\
\hline $\mathrm{T}-90-45^{\circ}-\mathrm{n} 1$ & 17 & & - & 253 & 1 \\
\hline T-90-45-n2 & 18 & & - & 257 & 2 \\
\hline $\mathrm{T}-0 / 90-20^{\circ}-\mathrm{n} 1$ & 26 & & 288 & 252 & 3 \\
\hline T-0/90-45ºn1 & 24 & & 286 & 281 & 5 \\
\hline $\mathrm{T}-0 / 90-45^{\circ}-\mathrm{n} 2$ & 23 & & 280 & 275 & 3 \\
\hline $\begin{array}{l}\text { Mean crushing stress } \\
\text { from all points }\end{array}$ & 194 & & 277 & 270 & 4 \\
\hline $\begin{array}{l}\text { Cytec balanced fabrics } \\
\text { Specimen }\end{array}$ & & \multicolumn{2}{|c|}{$\begin{array}{l}\text { No. of points } \\
\text { for LMS } \\
\text { calculation }\end{array}$} & $\begin{array}{l}\sigma_{0^{\circ}} \\
(\mathrm{MPa})\end{array}$ & $\begin{array}{l}\text { Standard } \\
\text { deviation } \\
(\%)\end{array}$ \\
\hline $\mathrm{C}-0-5^{\circ}-\mathrm{n} 1$ & & \multicolumn{2}{|l|}{23} & 275 & 7 \\
\hline $\mathrm{C}-0-20^{\circ}-\mathrm{n} 1$ & & \multicolumn{2}{|l|}{24} & 270 & 6 \\
\hline $\mathrm{C}-0-45^{\circ}-\mathrm{n} 1$ & & \multicolumn{2}{|l|}{26} & 269 & 6 \\
\hline \multicolumn{2}{|c|}{$\begin{array}{l}\text { Mean crushing stress from all } \\
\text { points }\end{array}$} & \multicolumn{2}{|l|}{73} & 272 & 7 \\
\hline
\end{tabular}

mean crushing stress of $0^{\circ}$ and $90^{\circ}$ ply inside laminate can be estimated separately.

$F=\sigma_{0^{\circ}} S_{0^{\circ}}+\sigma_{90^{\circ}} S_{90^{\circ}}+F_{\text {splaying }}$

The estimation of mean crushing stress is done by using the least mean square (LMS) method. In both models, the value of $F_{\text {splaying }}$ is neglected for further analysis due to the same reason discussed in the previous section. All the results of mean crushing stress for each case are presented in Table 2.

The calculation of the last row for both parts of the table corresponds to the results of mean crushing stress for all tests on each material. It corresponds to a LMS executed on all points, i.e. 194 data points from laminate and UD specimens of material T700/ M21 and 73 data points from the woven specimens (one data point refers to one image taken from the tests). On this calculation, the maximum error between the experimental force and the calculated force for both cases are $12 \%$ and $10 \%$ respectively, and the standard deviation are $4 \%$ and $7 \%$ respectively.

In fact, for T700/M21 specimens the domain of calculation for LMS is relatively wide, as there are pure $0^{\circ}$, pure $90^{\circ}$, mixed $0^{\circ}$ and $90^{\circ}$ (with different ratio in contact area), and different levels of crushing area in each case as shown in Fig. 6. All experiment data are well fitted by an interpolating plane which validates the prediction model B is suitable to be used to estimate the mean crushing stress of a ply. Furthermore, Fig. 7 shows good correlation between estimated forces from prediction models determined by LMS and force from experiment on different specimens for both materials.

\section{Discussion}

The proposed method works well in determining the mean crushing stress. From the calculations (LMS) on T700/M21, it shows that whatever the test used (only UD or laminate), the mean crushing stress is almost the same in each ply:

$$
\begin{gathered}
\left.\underset{(273 \mathrm{MPa})}{\sigma_{0^{\circ}(\mathrm{UD} \text { onl })}} \approx \sigma_{0^{\circ}\left(\mathrm{UDO}^{\circ}\right.} \text { in } 0 / 90 \text { laminate }\right) \\
(280 \mathrm{MPa})
\end{gathered}
$$

where the mean crushing stress values above was taken from separate LMS correlation on all T- 0 specimens, T-90 specimens and T-0/ 90 specimens respectively.

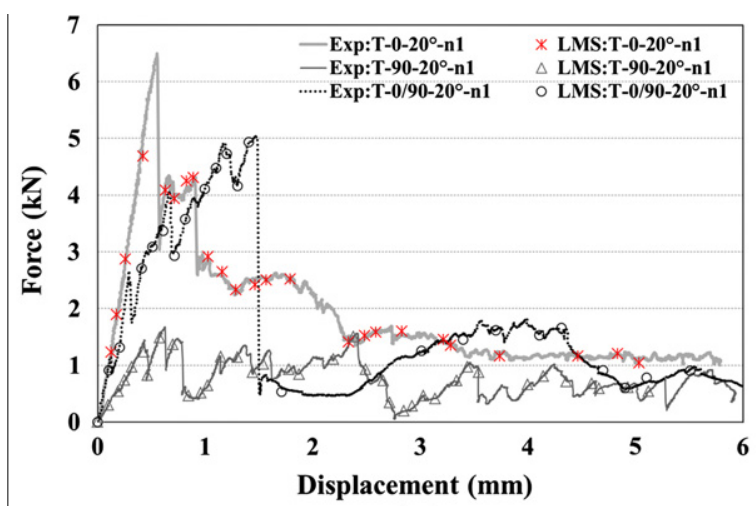

(a)

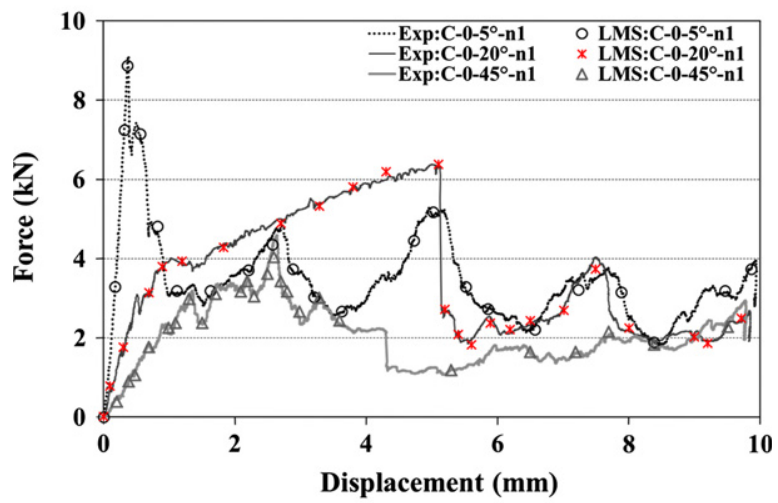

(b)

Fig. 7. Example of experiment and LMS correlation: (a) T700/M21 laminates, and (b) Cytec balanced fabrics laminate.

Besides that, by combining all data points of UD and laminate specimens, the final $\sigma_{90^{\circ}}$ obtained is $272 \mathrm{MPa}$ which is very close to the value of transverse compressive strength. The explanation is that in the crushing zone, the main failure mechanism is the same: shear fracture at $45^{\circ}$, like seen in Fig $8 \mathrm{~b}$, which shows the crushed surface of a $90^{\circ}$ ply under SEM after release of the crushing load. In contrast, the final $\sigma_{0^{\circ}}$ obtained is $277 \mathrm{MPa}$, which is far lower compared to longitudinal compressive strength, $1015 \mathrm{MPa}$. This is due to the difference in failure mechanisms where longitudinal compressive strength is induced by kink band [22] inside $0^{\circ}$ plies, whereas $\sigma_{0}$ is obtained from fragmentation at the extremity of the plies, where confinement of fibers is lower, and the surface is irregular, due to the presence of packs of fibers with pre-initiated inter- and intra-laminar cracks. Fig 8a shows the crushed surface of a $0^{\circ}$ ply, under SEM, after release of the crushing load. The irregularities of the surface of crushing are obvious on the photography: packs of fibers and powder-like debris.

Furthermore, even if the models of calculation are different, depending on the laminate types: model A on UD laminates, model $\mathrm{B}$ on $\mathrm{T}-0 / 90$ laminate, or model B on all laminates, the calculated mean crushing stress for $0^{\circ}$ and $90^{\circ}$ comparatively are always very close. It means that when a steady fragmentation is obtained during crushing in $0^{\circ}$ or $90^{\circ}$ plies, both plies have the same energy absorption ability. This result must be qualified by the observations made during tests. $0^{\circ}$ plies crushing tests show the possibility for a part of the plies to create a steady fragmentation, whereas in $90^{\circ}$ tests, most of the time, fragmentation turns to global rupture of the ply (see big fragment in Fig 4b). In that case, the volume of material actually involved in energy absorption is then lower.

The same method and steps are used for the analysis of laminates made of Cytec balanced fabric material (C-0). All tests were 

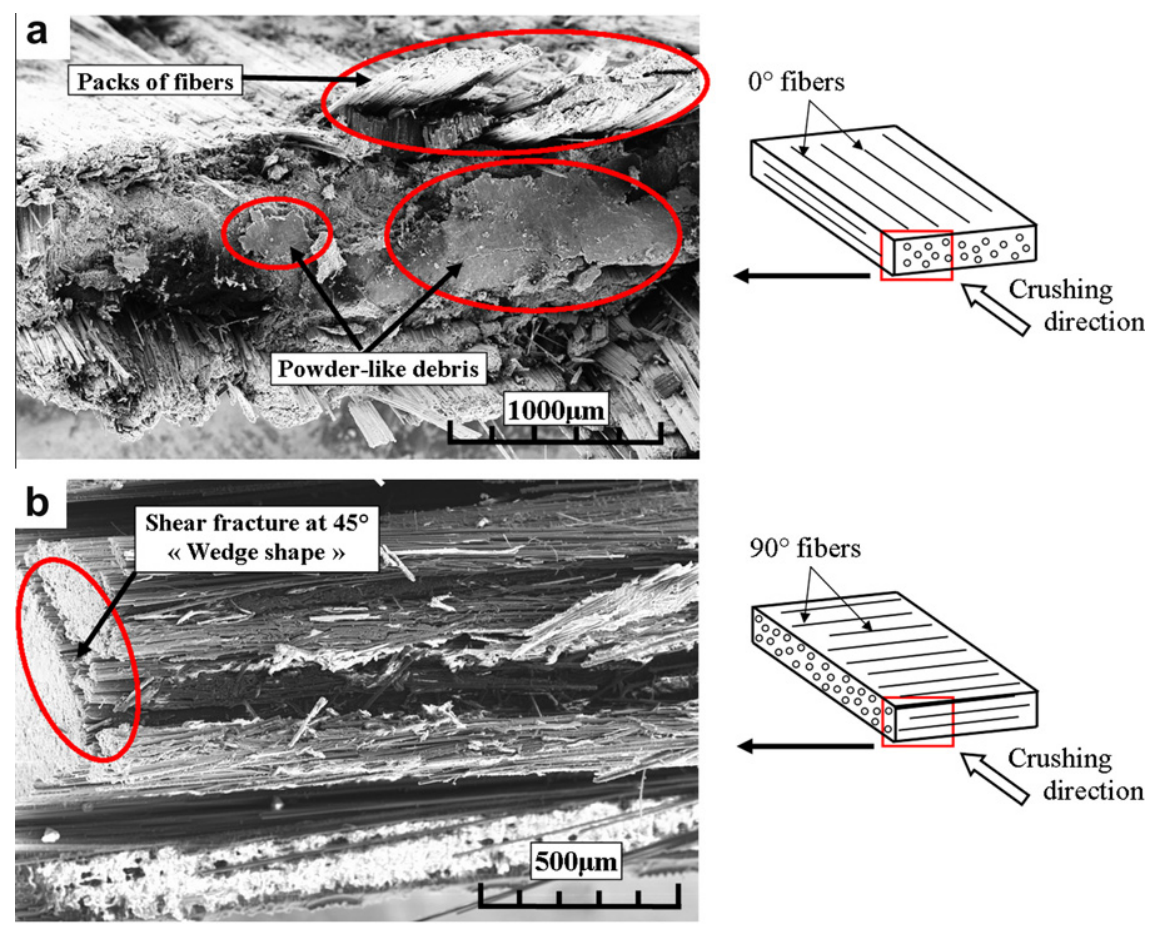

Fig. 8. SEM observation of crushed surface: (a) T-0 specimen, and (b) T-90.

done in the warp direction of the fabric. Therefore, the model used is model A (only one parameter). Only plies or part of plies in fragmentation are taken into account for the calculation of contact area. The result of mean crushing stress for this laminate (272 $\mathrm{MPa}$ ) is also close to the results of global mean crushing stress of T700/M21 plies, even if there is no particular relation between these two materials. This value is also considerably far below the compressive strength of warp plies and $877 \mathrm{MPa}$ ).

Moreover, from the mean crushing stress obtained in this study the equivalent SEA, a frequent used parameter to specify the energy absorption capability can be computed for both materials by:

$\mathrm{SEA}=\frac{E_{\text {total }}}{M_{\text {crush }}}=\frac{F_{\text {mean }} \cdot L_{\text {crush }}}{\rho S L_{\text {crush }}}=\frac{\sigma_{\text {mean }}}{\rho}$

where $E_{\text {total }}, M_{\text {crush }}, L_{\text {crush }}, \rho, S$ are the total energy absorb during crushing, the mass of the crushed material, the final crushing length, the density and cross-sectional area, respectively. While, $F_{\text {mean }}$ is mean crushing load and $\sigma_{\text {mean }}$ is mean crushing stress. Hence, for T700/M21 the calculated SEA for $0^{\circ}$ plies is $185 \mathrm{~kJ} / \mathrm{kg}$ and $180 \mathrm{~kJ} / \mathrm{kg}$ for $90^{\circ}$ plies. These SEA values are also close to the calculated SEA of Cytec balanced fabrics which is $183 \mathrm{~kJ} / \mathrm{kg}$ because of the small difference in density between these two materials. However, these SEA values are ideal values, only obtained if laminates are crushed entirely in fragmentation mode which is not the case in most of tests available in the literature. Thus, these SEA results are much higher than SEA values (range from 50 to $95 \mathrm{~kJ} / \mathrm{kg}$ ) found in the literature [4,23,24] of other carbon/epoxy types with different geometry configurations.

The nearest SEA value found in literature is $194 \mathrm{~kJ} / \mathrm{kg}$ obtained by Ramakrishna [25], but with a different type of resin: polyetheretherketone (PEEK).

\section{Conclusions}

An investigation to determine the local mean crushing stress of a ply inside a laminate has been done with a simple methodology based on images analysis. The qualitative agreement between the correlation of force/surface analysis by LMS and the experimental data was demonstrated. It shows that it is possible to calculate a mean crushing stress for plies being crushed in a fragmentation mode with the proposed test and calculation method since the correlation is done all along the crushing progression and not at a specific point of the test.

For $0^{\circ}$ and $90^{\circ}$ plies, the values calculated in pure $0^{\circ}$ ( or $90^{\circ}$ ) or in $0^{\circ} / 90^{\circ}$ laminate are the same, which allows to say that, at least for beam-like or plate-like structures, the value of the mean crushing stress of a ply is an intrinsic parameter of the material, even if it does not involve that during crushing, all plies, or even all the thickness of a ply will crush in a fragmentation mode.

This test and calculation method could then be used as a test characterization of material for the purpose of crushing simulation.

Furthermore, the values of mean crushing stress for $0^{\circ}, 90^{\circ}$ in UD T700/M21 and also in the Cytec fabric where found to be very close, around $270 \mathrm{MPa}$.

From a numerical point of view, this study demonstrates the potential to deliver essential data regarding the magnitude of the mean crushing stress to perform numerical simulations of crushing at a mesoscopic scale using the mean crushing stress of a material as an input parameter.

\section{Acknowledgements}

The authors gratefully acknowledge the CYTEC for the free supply of materials and the Ministry of Higher Education, Malaysia (MOHE) for the financial support of Ph.D. program through the Aerospace Scholarship Scheme.

\section{References}

[1] Hull D. A unified approach to progressive crushing of fiber reinforced tubes. Compos Sci Technol 1991;40:377-421.

[2] Mamalis A, Robinson M, Manolakos D, Demosthenous G, Ioannidis M, Carruthers J. Crashworthy capability of composite material structures. Compos Struct 1997;37:109-34. 
[3] Barnes G, Coles I, Roberts R, Adam DO, Garner DM. Crash safety assurance strategies future plastic and composite intensive vehicles (PCIVs). Volpe National Transportation Systems Center, final report; June 2010.

[4] Lavoie JA, Kellas S. Dynamic crush tests of energy-absorbing laminated composite plates. Composites Part A 1996;27A:467-75.

[5] Kim JS, Yoon HJ, Shin KB. A study on crushing behaviors of composite circular tubes with different reinforcing fibers. Int J Impact Eng 2011;38:198-207.

[6] Joosten MW, Dutton S, Kelly D, Thomson R. Evaluation of a predictive stackedshell analysis methodology for the analysis of energy absorbing composite crush elements. In: Proceeding of the 14th European conference on composite materials (ECCM/14), Budapest; 7-10 June 2010.

[7] Czaplicki MJ, Robertson RE. Comparison of bevel and tulip triggered pultruded tubes for energy absorption. Compos Sci Technol 1991;40:31-46.

[8] Jiménez MA, Miravete A, Larrodé E, Revuelta D. Effect of trigger geometry on energy absorption in composite profiles. Compos Struct 2000;48:107-11.

[9] Feraboli P, Wade B, Deleo F, Rassaian M. Crush energy absorption of composite channel section specimens. Composites Part A 2009;40:1248-56.

[10] Melo JD, Silva AL, Villena JE. The effect of processing conditions on the energy absorption capability of composite tubes. Compos Struct 2008;82:622-8.

[11] Hamada H, Ramakrishna S. Crushing mechanism of carbon fiber/PEEK composite tubes. Composites 1995;26:749-55.

[12] Hadavinia H, Ghasemnejad H. Effects of mode-I and mode-II interlaminar fracture toughness on the energy absorption of CFRP twill/weave composite box sections. Compos Struct 2009;89:304-14.

[13] Sigalas I, Kumosa M, Hull D. Trigger mechanism in epoxy-absorbing glass cloth/epoxy tubes. Compos Sci Technol 1991;40:265-87.

[14] Warrior NA, Turner TA, Cooper E, Ribeaux M. Effects of boundary conditions on the energy absorption of thin-walled polymer composite tubes under axial crushing. Thin Wall Struct 2008;46:905-13.

[15] Savona SC, Hogg PJ. Effect of fracture toughness properties on the crushing of flat composite plates. Compos Sci Technol 2006;66:2317-28.
[16] Farley GL, Jones RM. Analogy for the effect of material and geometrical variables on energy-absorption capability of composite tubes. J Compos Mater 1992;26:78-89.

[17] Greve L, Pickett AK, Payen F. Experimental testing and phenomenological modelling of the fragmentation process of braided carbon epoxy composite tubes under axial and oblique impact. Composites Part B 2008;39:1221-32.

[18] Duong AV, Rivallant S, Barrau JJ, Petiot C, Malherbe B. Influence of speed on the crushing behavior of composite plates. In: Proceeding of the 7th AsianAustralasian conference on composite materials (ACCM/7), Taipei; 15-18 November 2010.

[19] Mamalis A, Robinson M, Manolakos D, Demosthenous G, Ioannidis M. The static and dynamic axial collapse of fiber glass composite automotive frame rails. Compos Struct 1996;34:77-96.

[20] Palanivelu S, Paepegem MV, Degrieck J, Vantomme J, Kakogiannis D, Ackeren JV, et al. Crushing and energy absorption performance of different geometrical shapes of small-scale glass/polyester composite tubes under quasi-static loading conditions. Compos Struct 2011;93:992-1007.

[21] Guillon D, Rivallant S, Barrau JJ, Petiot C, Thevenet P, Malherbe B. Experimental and numerical study of the splaying mode crush of CFRP laminates. In: Proceedings of the 17th international conference on composite materials (ICCM/17), Edinburgh; 27-31 July 2009.

[22] Schultheisz CR, Waas AM. Compressive failure of composites, part I: testing and micromechanical theories. Progr Aerosp Sci 1996;32:1-42.

[23] Farley GL, Jones RM. Crushing characteristics of continuous fiber-reinforced composite tubes. J Compos Mater 1992;26(1):37-50.

[24] Bolukbasi AO, Laananen DH. Analytical and experimental studies of crushing behavior in composite laminate. J Compos Mater 1995;29:1117-39.

[25] Ramakrishna S. Microstructural design of composite materials for crashworthy structural applications. Mater Des 1997;18(3):167-73. 